\title{
Quality Management and Best Practices: An Experiential Learning Model for Higher Education with a special reference to Laxmi Memorial Education Trust ${ }^{\circledR}$
}

\section{* Mrs Ashritha P. Shetty}

\section{Abstract}

Education helps men and women claim their rights and realize their potential in the economic, political and social arenas. It is also the single most powerful way to lift people knowledge-based society. Further, higher educational institutions contribute to the growth of the nation by providing specialized knowledge and skilled work force.. Education helps men and women claim their rights and realize their potential in the economic, political and social arenas. It is also the single most powerful way to lift people knowledge-based society. Further, higher educational institutions contribute to the growth of the nation by providing specialized knowledge and skilled work force. Though India has a very large population of youth who look up for higher education, the number and percentage of students enrolling for higher education and professional courses are far below the world average. Educational institutions have realized that in the highly competitive environment, students can be attracted to them only by providing the best in terms of facilities and inputs. But, there is still no universal consensus on how best the quality can be managed within higher education.

The present study tries to understand and report the views and perceptions of heads of educational institutions, faculty and the students from selected five institutions functioning under Laxmi Memorial Education Trust ${ }^{\circledR}$ (LMET), with reference to quality on various dimensions and to develop a model based on the research indication received.

Key words: Higher Education, Quality in higher education, Private sector,

* Director, Laxmi Memorial Educational Trust, Mangalore 


\section{Introduction}

Education, especially the higher education, is constantly growing as knowledge-based industries are occupying the centre stage in the process of development. Its role has been redefined as the process of imparting knowledge which is essential, skills which are relevant and the values which are foundational. In the present scenario, the educational institutions face very stiff competition. In addition, the stakeholders expect impeccable quality in terms of educational outputs. These two factors have rendered the management of educational institutions more difficult. India has a very large population of youth who look up for higher education. Despite, the number and percentage of students enrolling for higher education and professional courses are far below the world average. Poverty among the lower and middle class parents is the major factor inhibiting students from availing higher education. Nevertheless, the admissions to colleges have risen substantially in recent years. Educational institutions have realized that in the highly competitive environment, students can be attracted to them only by providing the best in terms of facilities and inputs. In recent years, with the realization of significance of higher education in the emerging economy and the problems associated with its quality, there has been a wide range of discussions on the term 'quality' in higher education.

\section{Higher Education Scenario in India and Dakshina Kannada: A Revisit of the Practices Ensuring the Quality}

India as a developing nation has been systematically progressing on the educational front since its independence and has seen an appreciable surge in reaching out to all the classes of its society. The improvement on the country's economic front, the up-scaling of communication, technology and the advent of the internet, have vastly leveraged the promotion of education across all verticals. The accelerated growth of the educational sector in last decade is a sparkling testimony to this fact, with facts and figures showing an unprecedented improvement of education in India.

The 'Right to Education Act' which stipulates compulsory and free education to all children in the age group of 6-14 years, has brought 
about a revolution in the education system of the country with statistics revealing a staggering enrolment in schools over the last four years. The educational movement has been receiving tremendous government support through comprehensive planning in its various Five Year Plans. Additionally the active involvement of the private sector has begun to demonstrate significant reach and improvement in the Indian education system.

India's higher education system stands third in size in the world after the US and China with nearly 26 million students enrolling in over 45,000 institutions in the country. Particularly In the last decade the country has witnessed a high growth rate of 10.8 per cent and 9 per cent in student enrolment at CAGR and institutions, respectively. The University Grants Commission (UGC) which enforces its standards is the main governing body at the tertiary level.

Indian higher education has been progressing at a fast pace adding over 20,000 colleges and about 8 million students during the ten year period of 2001 - 2011. As of 2011, Indian higher education system is spread over 42 central universities, 275 state universities, 130 deemed universities and 90 private universities. Additionally 5 institutions were established functioning under the State Act, along with 33 Institutes of National Importance. Nearly 33,000 institutions function as Government and Private Degree Colleges which also include 1800 women's colleges.

Today the number of private higher education institutions stands at 64 per cent and student enrolments at 59 per cent of the total number of institutions and enrolments in the country making India home to the largest number of Higher Education institutions in the world, with second highest student enrolments. This is a significant jump from the figures recorded a decade before, where private institutions stood at 43 per cent and enrolments at 33 per cent. This is an obvious index to the improving educational system through private participation.

The current emphasis in Indian higher education has been placed mainly on science and technology. Distance learning and open education are the two essential features of the Indian higher education system. Indira Gandhi National Open University run by 
the Indian government is attributed to be the largest university in the world by number of students with over 3.5 million students from across the globe. Premium institutions of India, such as the Indian Institutes of Technology (IITs), Indian Institutes of Management (IIMs), National Institute of Technology (NITs) and Jawaharlal Nehru University have attained global acclamation for their high standard of education. About 8000 students are enrolled annually by the IITs and the alumni have made significant contributions to the growth of both, the private sector and the public sector of India.

At the end of the eleventh Five Year Plan (2007-2012), India has achieved a Gross Enrolment Ratio (GER) of 17.9 per cent an increase from 12.3 per cent the figure at the beginning of the plan period. The twelfth five year plan of the Indian government for 2012-1217 envisages several revolutionary initiatives to exponentially improve the quality and reach of higher education across the length and breadth of the country. (Obadya Ray Shaguri EAN World Congress Scholar, 2013)

Dakshina Kannada has always been considered as one of the most sought-after education destinations, especially Mangalore, which provides quality education in higher and professional courses. The District is a home for a wide variety of schools, engineering and medical institutions. A host of educational institutes offering courses in Medicine, Engineering, Pharmacy, Nursing, Hotel and catering, Law and Management are located in this District. The District is a home to research institutes like National Research Centre for Cashew at Puttur and Central Plantation Crops Research Institute at Vitla. The data as reported by District administration for the year 2015-2016 reveal that there are four medical colleges catering to the needs of 1850 students five dental colleges with 1201 students. 18 engineering colleges having 31046 students. Also there are 12 Polytechnic Colleges with 3206 students. The total number of Degree Colleges is 143 with 49937 students (20036 boys and 29901 girls) pursuing degree education.

\section{Laxmi Memorial Trust $®$ - the Parent Institution}

The Laxmi Memorial Trust $@$, (LMET), the parent institution of the 
sample units, was propounded in 1992 by the well known industrialist, social worker and munificent philanthropist Dr. A.J. Shetty in the memory of his mother, late Mrs. Laxmi Shetty. LMET made its humble beginning with an Institution for Hotel Management and today, it has grown into manifold to the extent of an academic empire of excellence and quality by establishing a multi-campus network of medical, dental, paramedical and management studies.

\section{Profile of the Sampling Units}

Among the Institutions functioning under the Laxmi Memorial Trust, five Institutions are considered as the sample units for the study The Institutions selected for the study are: A.J. Institute of Management, Laxmi Memorial College of Physiotherapy, Laxmi Memorial College of Nursing, Moti Mahal College of Hotel Management and Laxmi Memorial college of Hotel Management.

\section{Laxmi Memorial College of Nursing}

Laxmi Memorial College of Nursing was established in the year 1997. It is one of the beginning educational endeavors of L.M.E.T The College is affiliated to Rajiv Gandhi University of Health Sciences, Bangalore and is permanently recognized by the Indian Nursing Council [INC] New Delhi and Karnataka State Nursing Council Bangalore. Together there are 599 students pursuing their nursing education

\section{Laxmi Memorial College of Physiotherapy}

Laxmi Memorial College of Physiotherapy was established in the year 1993. In the beginning the College was affiliated to Mangalore University, and since 1997the college is affiliated to Rajiv Gandhi University of Health Sciences (RGUHS) Karnataka. Presently the College is approved for 100 Bachelor of Physiotherapy (BPT) seats and 30 Master of Physiotherapy (MPT) seats. It is also a recognised $\mathrm{Ph} . \mathrm{D}$ centre under RGUHS since the year 2010. The College runs a physiotherapy clinic in the college premises.

\section{Moti Mahal College of Hotel Management}

It offers the Bachelor's degree Course in Hotel Management (BHM). affiliated to Mangalore University and Recognized by AICTE, New Delhi. The mission of the Moti Mahal College of Hotel Management 
is to provide a full educational experience to students, creating an environment in which students will develop intellectually and personally. Totally there are 210 students pursuing their hotel management education.

\section{Laxmi Memorial College of Hotel Management}

Laxmi Memorial College of Hotel Management was started in 2008. The College is affiliated to Mangalore University and is offering $3 \mathrm{yr}$ B.Sc. (H.S) programme. In total there are 199 students pursuing B.Sc (Hospital Sciences)

\section{A. J. Institute of Management}

A.J. Institute of Management is the stand-alone Institute offering Two-year full time MBA programme, affiliated to Mangalore University and recognized by AICTE, New Delhi and Govt. of Karnataka. NAAC has accredited the institute at "B+" with CGPA 2.67 The Institute has begun its journey in 1999, There are 211 students pursuing MBA programme.

\section{Need for the Study}

Despite the process that has been made through research and debate, there is still no universal consensus on how best the quality can be managed within higher education. One of the key reasons for this is the recognition that quality is a complex and multi-faceted construct, particularly in Higher Education Environments (Harveyand Knight, 1996; Cheng and Tam, 1997, Becket and Brookes, 2006). As a result, the measurement and management of quality has created a number of challenges. Hence, there is a need to study various quality parameters on the perspectives of Institutions, teachers and students.

Institutions functioning under the Laxmi Memorial Education Trust (LMET) aim to focus on providing quality education in all facets of higher education. It is a matter of the fact that parameters of quality keep changing. The proposed study aims at determining the best practices adopted by the Institution for its continuous growth and to create a learning model for the system of Higher Education ensuring the education of quality and excellence. Further, as a means of introspection, the present study is intended to understand the present perception of the institutions functioning under Laxmi Memorial 
Education Trust, Mangalore with regard to the quality and the best practices in the field of higher education. It is also believed that the outcomes of the study will also plug the loopholes if any, in the academic delivery and also to improve further the existing areas. In fact, it is an attempt to revisit the quality and best practices of the select institutions functioning under the Trust and to make necessary changes, based on the outcomes received.

\section{Research Objectives}

The central purpose of this research study is to and report the views and perceptions of heads of educational institutions, faculty and the students functioning under LMET, with reference to quality on various dimensions and to develop a model based on the research indication received. However, the specific objectives are

1. To provide an insight into the higher education scenario in India and Dakshina Kannada District and sense of quality prevailing.

2. To provide a bird's eye view of institution's functioning under Laxmi Memorial Education Trust $(\circledR$ and the programmes offered by them.

3. To study the performance of select institutions under Laxmi Memorial Education Trust on Identified Parameters of Quality and Best Practices.

4. To study the views and perceptions of teachers on their role performance in terms of identified parameters of: i) Teaching ii) Research iii) Extension

5. To study views and perception of students with regard to quality of higher education and its relevance in the era of globalization in terms of certain identified parameters of quality in higher education.

6. To build a socially acceptable and economically feasible learning model for quality management and best practices in higher education based on research indications.

\section{Limitations of the Study}

The proposed study is confined only to: 
(i) The select institutions functioning under Laxmi Memorial Education Trust providing Higher Education.

(ii) Views and perception of teachers with regard to three major functions i.e. teaching, research and extension.

(iii) Views and perceptions of students with regard to quality and relevance of higher education in globalizing economic order.

\section{Methodology}

Three separate sets of questionnaires were prepared and administered among the heads, faculty members and students respectively from these five sample Institutions. The questionnaires were personally administered to 35 faculty members of these five sample Institutions. For the current study, 49 students pursuing their nursing programme, 20 students studying physiotherapy course, 20 students pursing MBA programme, 20 students studying Hotel Management and 20 students B.Sc. in Hospitality Science are randomly selected. However, to the heads of the sample Institutions, the questionnaires were administered through structured one-to-one interaction. A brief profile of sample units is given below.

The collected data was analysed using the qualitative techniques of interpreting the data in the present study.

\section{Review of Literature}

A brief review of literature related to the present study brings out the following outcome:

It is argued that quantitative approaches do not currently offer potential to assess teaching quality and are unlikely to do so in the given current structure of higher education. The greatest promise lies in the external scrutiny recently instituted by the Higher Education Funding Councils and the Higher Education Quality Council. Sharp S (1995)

Woollard A(1995) suggests that quality in education is a synthesis of current approaches - one originating within the philosophy of higher education and another emerging from the demands of employers with a focus on 'core skills' answering the question to the satisfaction of all stakeholders, whilst preserving essential academic autonomy. 
Self-regulation of the Institute supported by external peer review will ensure the quality in higher education Watson D (1995)

Stephen Sharp S, Munn P, Paterson L (1997) states that Quality assessment has been a feature of higher education in Scotland for the academic years from 1992 to 1996 . The study observed, firstly to present the profile of opinion amongst 366 respondents to the questionnaire and secondly to investigate whether any patterns are discernible within this group. Indications suggest that the quality in every facets of education is the result of the philosophy of individuals and the Institutions.

Likewise, the study conducted by Srikanthan G and Dalrymple J (2006) revealed that the generic nature of actions to set in motion the learning cycle are: 'guiding ideas', which provide a sense of purpose; 'theory, methods and tools' to allow people to learn new skills; 'innovations in infrastructure' to give people an opportunity to pursue their vision.

Gunduz N and Ozcan D (2010) Learning styles are seen to be important to consider in the educational process of the academic world which is also supported by literature. Among other variables, differences of learning styles may be influenced by language, culture, educational department and gender. The study reported the influence of culture, gender, native language and department on learning styles.

Ahmad, Wana and Jiana (2010) suggested that Virtual World is one of the emerging technologies which can be used for teaching and training. Lots of rooms need to be improved of making it as vulnerable place for learning such as in teaching the course module and tracking student performance.

Bittarelli \& Rossi (2010) suggest that IT intervention in education in multimedia recording and post production, LMS management and tailoring, student enrolment database management, activity tracking and monitoring etc., provided positive results, costs have been optimized and administration time has been reduced.

The findings of the study conducted by Mangnale and Rajasekhara $M$ P (2011) confirmed that both the institutions and the students insisted for more constructive role from the Internal Quality Assurance Cell 
(IQAC) in protecting the quality of higher education with ample focus on library and community services.

A study conducted by Lodge J M and Bonsanquet A (2013), suggested that the learning sciences play a greater role in understanding quality learning in Universities. Likewise, mutuality (self-regulation) remains the dominant mode of control of quality assurance in the United Kingdom. Brown R (2013). Furthermore, Sudha $T$ (2013) reported that a challenge of foreign institutions entering the Indian higher education is going to pose the threat of even survival of poor performing institutions and many organizations have achieved excellence and competitive lead by putting into practice TQM policy.

Isabel et. al. (2015), reported that effective assessment is a very important aspect in education, influencing determinedly in the process of helping and encouraging the students to learn and understand their progresses in learning. Likewise, Sawanth G.D (2016), opined that the role of IQAC in maintaining quality standards in teaching, learning and evaluation becomes crucial.

Parrish. D.R (2016) suggest that a major agenda of higher education institutions is to equip students to be employable and 'future ready' graduates; achieve their professional and personal goals; and respond, in a socially responsible way, to the challenges of the $21^{\text {st }}$ Century.

\section{Analysis and Interpretation of the Data: Views and Perception of Students}

The analysis of the questionnaire administered among 49 students pursuing their nursing programme, 20 students studying physiotherapy course, 20 students pursing MBA programme, 20 students studying Hotel Management and 20 students B.Sc. in Hospitality Science provide an overview of opinion of sample students drawn from sample institution under the Trust.

An analysis of data and information collected is presented below: 
Table No 1: Demographic statistics of the sample respondents (Students)

\begin{tabular}{|l|l|c|c|}
\hline $\begin{array}{c}\text { Demographic } \\
\text { Variable }\end{array}$ & \multicolumn{1}{|c|}{ Category } & $\begin{array}{c}\text { No. of } \\
\text { Respondents }\end{array}$ & Percentage \\
\hline Gender & Male & 54 & 41.86 \\
& Female & 75 & 58.14 \\
\hline Age & 18years to 20 years & 62 & 48.0 \\
& 20 years to 23 years & 53 & 41.0 \\
& 23 years to 26 years & 5 & 3.8 \\
& 26 years to 29 years & 4 & 3.4 \\
& 29 years and above & 5 & 3.8 \\
\hline
\end{tabular}

Source: Primary Data

From Table No 1, it is evident that out of total respondents investigated for the study, 58.14 percent of them were female and 41.86 percent were male. From this we can infer that education is becoming important irrespective of gender classification.

It is observed that 48 percent of the respondents are between 18-20 years of age, while 41 percent of the students are between $20-23$ years of age. From this we can conclude that most of the students pursuing their studies in various Institutions of LMET fall between the age group of 18-23.

Table No 2 : Need based Education in the Institution

\begin{tabular}{|c|c|c|}
\hline Opinion & No. of Respondents & Percentage \\
\hline Yes & 128 & 99.2 \\
\hline No & 1 & 0.8 \\
\hline Total & $\mathbf{1 2 9}$ & $\mathbf{1 0 0}$ \\
\hline
\end{tabular}

Source: Primary Data

The above Table No 2 and below Figure No 1, highlight that an overwhelming percentage (99.2) of the students agreed that they are getting need based education in their respective institutions. Thus, we can conclude that the Institutions functioning under LMET are successful in meeting the need of the hour in providing required education. 
Figure No 1: Need based Education in the Institution

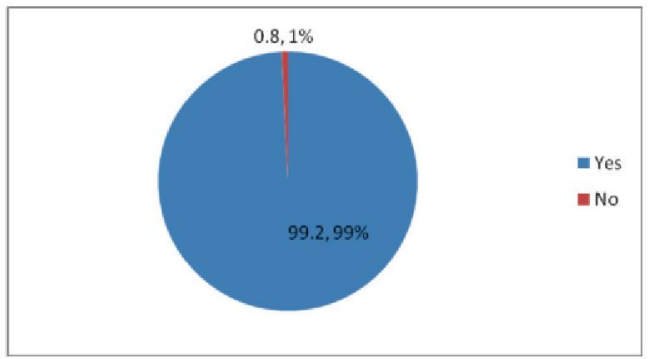

Table No 3 : Satisfaction level of available resources

\begin{tabular}{|c|c|c|c|}
\hline Opinion & Yes & No & Total \\
\hline Library & 124 & 5 & 129 \\
\hline E-Resources & 119 & 10 & 129 \\
\hline Computer Lab Activity & 128 & 1 & 129 \\
\hline
\end{tabular}

Source: Primary Data

Figure No 2: Satisfaction level of available resources

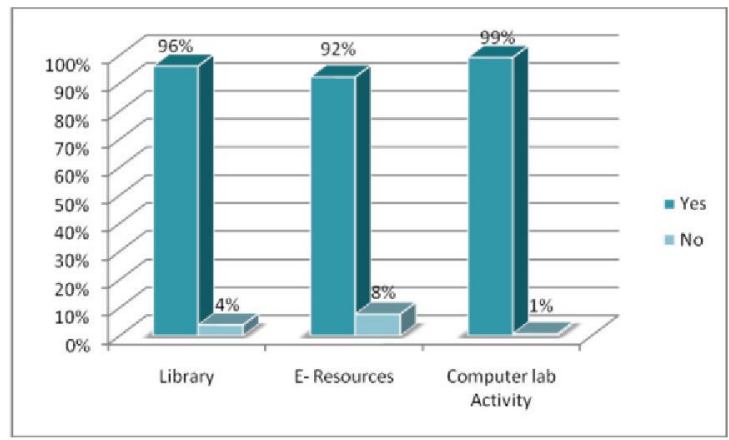

From the Table No 3 and Figure No 2, we can understand that 96 percent of students were satisfied with the library services provided at the Institute, 92 percent of the students with the E-resources and 91 percent of students are satisfied with the computer lab facilities at their respective Institutions. This infers that Institutions working under LMET are providing essential services and facilities towards quality enhancement of students. 
Table No 4 : Teaching supported by ICT facilities

\begin{tabular}{|c|c|c|}
\hline Opinion & No. of Respondents & Percentage \\
\hline Yes & 126 & 97.67 \\
\hline No & 3 & 2.33 \\
\hline Total & $\mathbf{1 2 9}$ & $\mathbf{1 0 0}$ \\
\hline
\end{tabular}

Source: Primary Data

Figure No 3: Teaching supported by ICT facilities

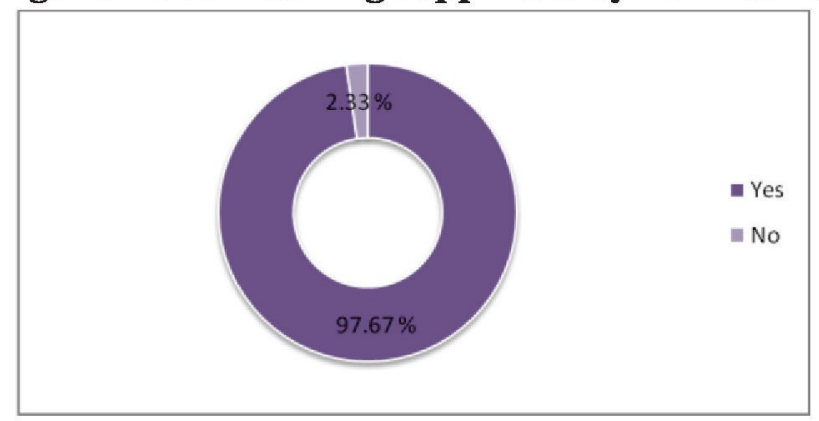

From the above Table No 4 and Figure No. 3, one can manifest that a majority of the students (97.67 percent) agree that their Institute is ICT enabled. Only a small percent of 2.33 felt that teaching is not supported by ICT.

Table No 5 : Satisfaction level regarding Curricular, Cocurricular and Extra-curricular activities

\begin{tabular}{|c|c|c|}
\hline Opinion & No. of Respondents & Percentage \\
\hline Yes & 124 & 97.6 \\
\hline No & 5 & 2.4 \\
\hline Total & $\mathbf{1 2 9}$ & $\mathbf{1 0 0}$ \\
\hline
\end{tabular}

Source: Primary Data

From the Table No 6 and Figure No 4, this we can understand that a majority (97.67) percent of students were satisfied with curricular, co-curricular and extracurricular activities organized by various Institutions functioning under LMET. Only 2.4 percent of the 
students are not satisfied with the curricular, co- curricular and extracurricular activities of the Institute. Thus, we can conclude that the Institutions under LMET are conducting good number of curricular, co- curricular and extracurricular activities to enhance the personality of the students.

Figure No 4: Satisfaction level regarding Curricular, Cocurricular and Extra-curricular activities

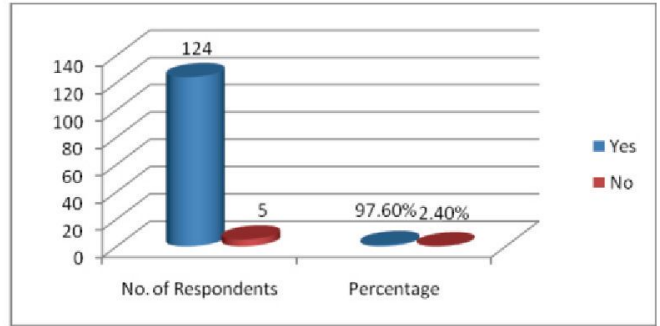

Table No 6 : Topics Taught provide new dimensions of knowledge

\begin{tabular}{|c|c|c|}
\hline Opinion & No. of Respondents & Percentage \\
\hline Yes & 124 & 97.6 \\
\hline No & 5 & 2.4 \\
\hline Total & $\mathbf{1 2 9}$ & $\mathbf{1 0 0}$ \\
\hline
\end{tabular}

Source: Primary Data

Figure No 5: Topics Taught provide new dimensions of knowledge

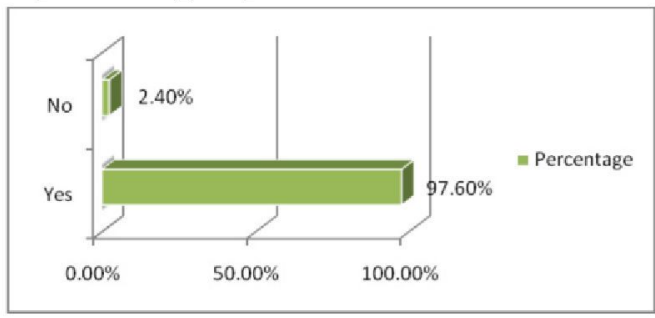

From the above Table No:6 and Figure No: 5 , we can understand that 97.6 percent of student respondents had an opinion that topics covered in the curriculum covered new dimensions of knowledge. This infers that different activities organized by the Institutions towards enhancing the student's knowledge through new dimensions will make them more competitive. 
Table No 7 : ICT enabled teaching enhances the quality of learning process

\begin{tabular}{|c|c|c|}
\hline Opinion & No. of Respondents & Percentage \\
\hline Yes & 123 & 95.3 \\
\hline No & 6 & 4.7 \\
\hline Total & $\mathbf{1 2 9}$ & $\mathbf{1 0 0}$ \\
\hline
\end{tabular}

Source: Primary Data

Figure No 6: ICT enabled teaching enhances the quality of learning process

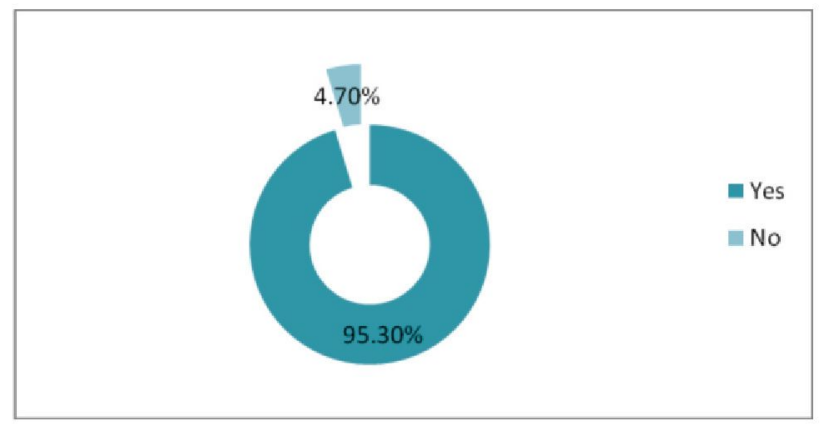

\section{Interpretation:}

From the above Table No 7 and Figure No 6, it is evident that 95.3 percent of the students had an opinion that ICT enabled teaching enhances the quality of learning process. This infers that the ICT facilities provided by various Institutions functioning under Laxmi Memorial Education Trust are reaching the target audience and they make the fullest use of the facilities.

Table No 8 : Academic Evaluation is fair and transparent

\begin{tabular}{|c|c|c|}
\hline Opinion & No. of Respondents & Percentage \\
\hline Yes & 125 & 96.8 \\
\hline No & 4 & 3.2 \\
\hline Total & $\mathbf{1 2 9}$ & $\mathbf{1 0 0}$ \\
\hline
\end{tabular}

Source: Primary Data 
Figure No 7: Academic Evaluation is fair and transparent

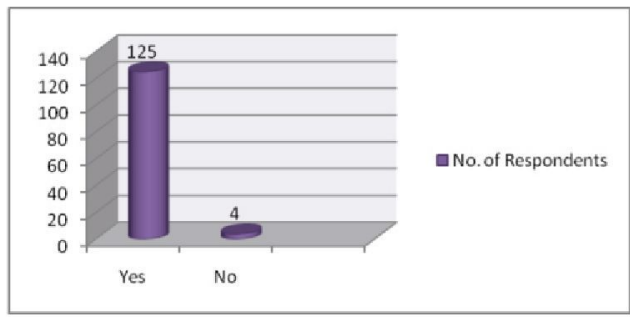

From the above Table No 8 and Figure No 7, it is evident that 96.8 percentages of students feel that the academic evaluation process is fair and transparent and only 3.2 percent of respondents opine that the academic evaluation process is not fair and transparent.

Table No 9: Evaluation Procedure and Practice adopted by Institute is Successful in evaluating performance in all dimensions

\begin{tabular}{|c|c|c|}
\hline Opinion & No. of Respondents & Percentage \\
\hline Yes & 127 & 98.4 \\
\hline No & 2 & 1.6 \\
\hline Total & $\mathbf{1 2 9}$ & $\mathbf{1 0 0}$ \\
\hline
\end{tabular}

\section{Source: Primary Data}

Figure No 8: Evaluation Procedure and Practice adopted by Institute is Successful in evaluating performance in all dimensions

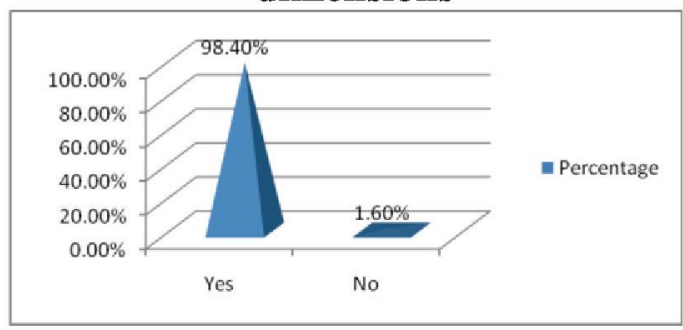

Above Table and Figure No 10, highlight that a majority of the respondents ( 98.4 percent) feel that the evaluation procedure and practice adopted by various Institutions are successful in evaluating performance of the students in all dimensions. This gives a clear identification that the evaluation process adopted gives importance to cover all parameters and dimensions in evaluating the students. 
Table No 10: Enhancement of Personality

\begin{tabular}{|c|c|c|}
\hline Opinion & No. of Respondents & Percentage \\
\hline Yes & 124 & 96.12 \\
\hline No & 5 & 3.88 \\
\hline Total & $\mathbf{1 2 9}$ & $\mathbf{1 0 0}$ \\
\hline
\end{tabular}

Source: Primary Data

Figure No 9: Enhancement of Personality

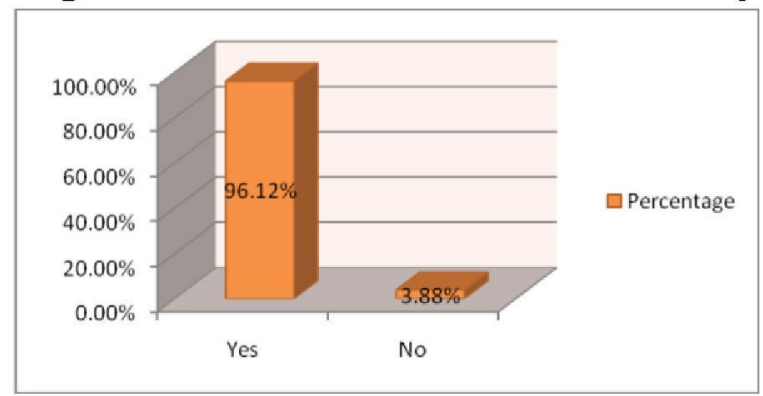

From the above Table No: 10 and Figure No 9, we can understand that majority (96.12) percent of students had an opinion that the quality and type of education offered by the Institutes has enhanced their personality. This infers that the motto of providing quality education by Laxmi Memorial Education Trust is met as students feel that the quality of education enhanced their personality.

Table No 11 : Add on Programs enhance skill set

\begin{tabular}{|c|c|c|}
\hline Opinion & No. of Respondents & Percentage \\
\hline Yes & 102 & 79.06 \\
\hline No & 27 & 20.94 \\
\hline Total & $\mathbf{1 2 9}$ & $\mathbf{1 0 0}$ \\
\hline
\end{tabular}

Source: Primary Data

From the above Table No 11 and Figure No 10, we can observe that 79.06 percent of students opines that add-on program enhances their skill set and 20.94 percent of students had a reverse opinion that addon programs will not have an impact on enhancing skill set. This 
infers that add-on programmes have impact towards enhancement of skill-set.

Figure No 10: Add on Programs enhance skill set

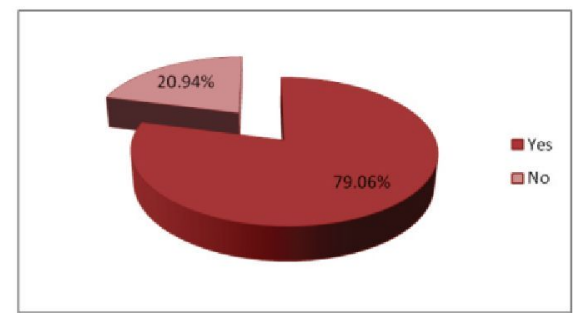

Table No 12 : Satisfaction with regard to Academic, Programmes and Facilities

\begin{tabular}{|c|c|c|}
\hline Opinion & No. of Respondents & Percentage \\
\hline Yes & 114 & 88.37 \\
\hline No & 15 & 11.63 \\
\hline Total & $\mathbf{1 2 9}$ & $\mathbf{1 0 0}$ \\
\hline
\end{tabular}

Source: Primary Data

Figure No 11: Satisfaction with regard to Academic,

Programmes and Facilities

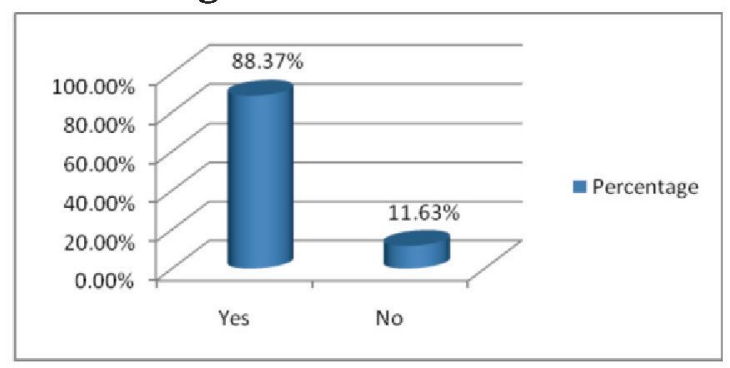

From the above Table No: 12 and Figure No 11, it is evident that a majority (88.37) percentage of students were satisfied with regard to academic, programmes and facilities provided by the Institutes. This infers that Institutes coming under the banner of Laxmi Memorial Education Trust were providing quality academic, programmes and facilities. 
Table No 13 : Recommendations to other aspirants

\begin{tabular}{|c|c|c|}
\hline Opinion & No. of Respondents & Percentage \\
\hline Yes & 120 & 93.02 \\
\hline No & 9 & 6.98 \\
\hline Total & $\mathbf{1 2 9}$ & $\mathbf{1 0 0}$ \\
\hline
\end{tabular}

Source: Primary Data

Figure No 12: Recommendations to other aspirants

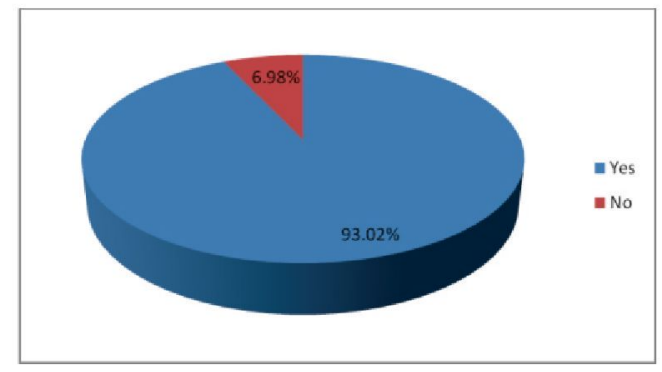

\section{Interpretation}

From the above Table No and Figure No 14, we can find that, majority (93.02) percent of students would recommend their institute to other aspirants among family and friends. This infers that LMET is successful in the implementation of various programmes for enhancing quality education to their students.

Analysis and Interpretation : Views and Perceptions of Teachers Teachers' beliefs, practices and attitudes are important for understanding and improving educational processes. They are closely linked to teachers' strategies for coping with challenges in their daily professional life and to their general well-being. Further, they also shape students' learning environment and influence student motivation and achievement. The questionnaires were personally administered to 35 faculty members of these five sample Institutions.

Following tables provide an overview of the views and perceptions of sample faculty about the various quality practices developed and implemented in their respective sample Institutions. 
Table No 14 : Table representing faculty strength of sample Institutions.

\begin{tabular}{|l|c|c|}
\hline \multicolumn{1}{|c|}{ Institution Name } & Number & Percentage \\
\hline $\begin{array}{l}\text { Laxmi Memorial College of } \\
\text { Physiotherapy }\end{array}$ & 07 & 20 \\
\hline $\begin{array}{l}\text { Laxmi Memorial College of Hotel } \\
\text { Management }\end{array}$ & 04 & 11 \\
\hline $\begin{array}{l}\text { Moti Mahal College of Hotel } \\
\text { Management }\end{array}$ & 08 & 23 \\
\hline Laxmi Memorial College of Nursing & 10 & 29 \\
\hline A. J. Institute of Management & 06 & 17 \\
\hline Total & 35 & 100 \\
\hline
\end{tabular}

Source: Primary Data

According to Table No. 14, the questionnaire- 2 was administered personally to thirty-five faculty, being randomly selected from five sample institutions.

Table No. 15 : Demographic statistics of the sample respondents (Faculty)

\begin{tabular}{|l|l|c|c|}
\hline $\begin{array}{c}\text { Demographic } \\
\text { Variable }\end{array}$ & \multicolumn{1}{|c|}{ Category } & $\begin{array}{c}\text { No. of } \\
\text { Respondents }\end{array}$ & Percentage \\
\hline Gender & Male & 15 & 43 \\
& Female & 20 & 57 \\
\hline Age & 22 years to 30 years & 14 & 40 \\
& 30 years to 40 years & 13 & 37 \\
& 40 years to 50 years & 8 & 23 \\
& 50 years and above & 0 & 0 \\
\hline Qualification & Graduate & 6 & 17 \\
& Post Graduate & 23 & 66 \\
& M. Phil & 2 & 06 \\
& Ph. D & 4 & 11 \\
\hline
\end{tabular}

Source: Primary Data 
Table shows that forty-three percent represent male and fifty seven percent represent female faculty (gender ratio of Male and Female is $3: 4)$.

One can infer that more than 75 percent of the respondents are in the age group of 22 years to 40 years. Hence, the data represents a good blend of young and experienced faculty. We can also note that no respondents were in the age group of 50 years and above.

From the above data, we can understand that the majority of the teaching faculty members are Post Graduates (66 percent), 17 percent of the respondents are Graduates, 17 percent of them are with higher qualification such as M. Phil and Doctoral Degree.

Table No 16: Average Classes Conducted per week

\begin{tabular}{|l|c|}
\hline \multicolumn{1}{|c|}{ Institution Name } & Average Classes \\
\hline Laxmi Memorial College of Physiotherapy & $5 \mathrm{hrs}$ \\
\hline $\begin{array}{l}\text { Laxmi Memorial College of Hotel } \\
\text { Management }\end{array}$ & $18.5 \mathrm{hrs}$ \\
\hline Moti Mahal College of Hotel Management & $22 \mathrm{hrs}$ \\
\hline Laxmi Memorial College of Nursing & $11.4 \mathrm{hrs}$ \\
\hline A. J. Institute of Management & $12.33 \mathrm{hrs}$ \\
\hline
\end{tabular}

Source: Primary Data

Table No.16 shows that both the Hotel Management Institutions have higher average hours as they have more time allocated to practical session along with the theory classes. It is evident that sufficient time space is available to the faculty working in the sample Institutions to take up research, extension and other quality enhancement exercises, in addition to reasonable teaching work load.

Interpretation: From the below Chart, we can infer that 51 percent respondents follow Case Study and Group Discussion and 71 percent of them use Assignment method to conduct classes, in addition traditional lecture method. It is a multiple-choice question and it is understood that faculties follow at least two methods of teaching. To make the class more interactive and to make effective two way 
process of communication, teachers follow modern methods of teaching along with the traditional lecture method.

Table No 17 : Teaching Method Adopted by Faculty

Respondents

\begin{tabular}{|l|c|c|}
\hline Teaching Method & Number & Percentage \\
\hline Lecture & 35 & 100 \\
\hline Case Study & 18 & 51 \\
\hline Group Discussion & 18 & 51 \\
\hline Assignment & 25 & 71 \\
\hline
\end{tabular}

Figure No 13 : Teaching Method Adopted by Faculty

Respondents

Method of Teaching adopted by

faculty

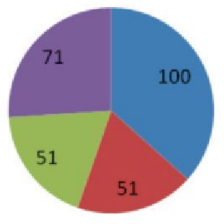

- Lecture

- Case Study

n Group Discussion

- Assignment

Table No 18 : Details of Participation of Sample Faculty in Conferences and Publication Activities

\begin{tabular}{|l|c|c|}
\hline & $\begin{array}{c}\mathbf{2 0 1 5 - 1 6} \\
\text { Total Number }\end{array}$ & $\begin{array}{c}\mathbf{2 0 1 6 - 1 7} \\
\text { Total Number }\end{array}$ \\
\hline Workshop/Seminar & 68 & 51 \\
\hline Conference & 42 & 46 \\
\hline Paper Presented & 15 & 20 \\
\hline Paper Published & 17 & 23 \\
\hline
\end{tabular}

Data Source: Primary Data

From the above Table No.18, we can understand that during the year 
2015-16, the faculty respondents have attended 68 workshops/seminars, 42 conferences and the total number of paper presentations is 15 and there are 17 quality publications. Likewise, for the year 2016-17, the participation of faculty in conference has increased to 46, Conference paper presentations in the conferences and seminars is 20 and total papers published was raised to 23 .

Figure No 14 : Details of Participation of Sample Faculty in Conferences and Publication Activities

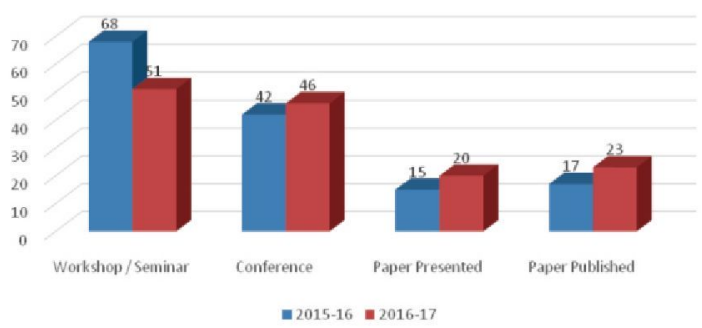

As per the figure 21 , there is a decrease of 25 percent in the workshop/seminar participation, 9 percent increase in the conference attended, 33 percent increase in paper presentation and 35 percent increase in the papers published during 201-17 compared to the previous year.

Table No 19: Response about Imparting knowledge beyond the course Content

\begin{tabular}{|l|c|c|}
\hline \multicolumn{1}{|c|}{ Imparting Knowledge } & Respondents & Percentage \\
\hline Yes & 33 & 94 \\
\hline No & 2 & 06 \\
\hline Total & $\mathbf{3 5}$ & $\mathbf{1 0 0}$ \\
\hline
\end{tabular}

Data Source: Primary Data

As per Table 19, 94 percent of the faculty respondents reported to impart knowledge beyond the course content to update the students with regard to social issues, general knowledge and knowledge related to business field is very much necessary as it would form a good base for students when they enter the job market. 
Table No 20 : Feedback from students regarding the teaching

\begin{tabular}{|l|c|c|}
\hline \multicolumn{1}{|c|}{ Feedback Status } & Respondents & Percentage \\
\hline Yes & 25 & 71 \\
\hline No & 10 & 29 \\
\hline Total & $\mathbf{3 5}$ & $\mathbf{1 0 0}$ \\
\hline
\end{tabular}

Data Source: Primary Data

As given in Table 20,71 percent of the faculty members take the feedback from the students regarding their teaching. This constructive feedback will help them to improve and to better their teaching skills. 29 percent of the faculties do not voluntarily take feedback from the students as they depend on feedback mechanism adopted by their Institute. Some Institutions follow feedback system after each semester through online method, exit interview or through the feedback collected in drop box. Certain Institutions also follows open door policy, wherein a student can approach the Institution head and give their feedback.

Table No 21 : Extension / Community Development should be a part of academics

\begin{tabular}{|l|c|c|}
\hline \multicolumn{1}{|c|}{ Rapport } & Respondents & Percentage \\
\hline Yes & 34 & 97 \\
\hline No & 1 & 03 \\
\hline Total & $\mathbf{3 5}$ & $\mathbf{1 0 0}$ \\
\hline
\end{tabular}

Data Source: Primary Data

Interpretation: Majority of the respondents i.e., 97 percent of the respondents felt that extension / community development activities should be a part of academics as they can sensitive issues to the young minds. Respondents also felt that social responsibility or doing something to the society should be imbibed in the early ages. 
Table No 22: Rapport with Parents about Academic Performance and Regularity of Their Ward

\begin{tabular}{|l|c|c|}
\hline \multicolumn{1}{|c|}{ Rapport } & Respondents & Percentage \\
\hline Yes & 27 & 77 \\
\hline No & 8 & 23 \\
\hline Total & 35 & $\mathbf{1 0 0}$ \\
\hline
\end{tabular}

Data Source: Primary Data

Interpretation: Institution should create platform, were in the teachers can keep the parents well informed about their wards' academic performance. This is required to ensure that the students remain focused on their studies. From the above data (Table No. 22) we can understand that 77 percent of the faculties do keep the rapport with the parents on updating their wards academic performance.

Table No 23 : Special Attention for slow learners

\begin{tabular}{|l|c|c|}
\hline \multicolumn{1}{|c|}{ Opinion } & Respondents & Percentage \\
\hline Yes & 34 & 97 \\
\hline No & 01 & 03 \\
\hline Total & $\mathbf{3 5}$ & $\mathbf{1 0 0}$ \\
\hline
\end{tabular}

Data Source: Primary Data

Majority of the faculty i.e., 97 percent, (Table No. 23) do give special attention for slow learners. The strategies adopted by them are:

a. By making the students to internalise the topic taught in simple terms

b. Mentor-Mentee system

c. Through Viva

d. Giving Assignments

e. Giving individual attention, by coaching the slow learns after regular class hours

f. By providing Remedial Classes 
Table No 24 : Participation in Extension / Community Development programme

\begin{tabular}{|l|c|c|}
\hline \multicolumn{1}{|c|}{ Opinion } & Respondents & Percentage \\
\hline Yes & 31 & 89 \\
\hline No & 04 & 11 \\
\hline Total & 35 & $\mathbf{1 0 0}$ \\
\hline
\end{tabular}

Data Source: Primary Data

As reflected in Table No. 24, most of the faculty members (89 percent) are the part of extension / community development programmes organized by their respective Institute or others.

Further, the sample faculty reported to have adopted different systems to a) enhance learning aptitude among the student, b) to ensure teaching-learning two way process and c) Ways of updating of knowledge in the field for their expertise. An overview of their views and perceptions to the above the following details are given.

a) Strategies adopted by the faculty to enhance learning aptitude among the student

Following strategies are observed by the faculty to enhance the learning aptitude among the students to make them to aspire to learn more.

- Provision of demonstration with examples to connect the theoretical concepts in the books to the real life situation.

- Using different teaching aids, focusing more on E-resources to make the teaching more interesting.

- Conducting group discussion to enables the students to put their views freely on a given a topic.

- Providing role playing or situation based learning to ensure hands on experience to students.

b) Strategies adopted to ensure teaching-learning a two way process

Two-way process of communication makes the class the interactive 
and interesting. Hence, following strategies are adopted by the sample faculty to ensure the teaching-learning a participative one.

- Group Discussion

- Giving interaction time at the end of the class about the course content covered

- Encouraging the students to give examples

- Making the students to recap of the previous days class in brief

- Case study discussion.

c) Ways of Updating of faculty knowledge in the field for their expertise:

A true teacher is to be a keen student. Updating their knowledge and keeping abreast with the changes help the teachers to cope with challenges in their daily professional life and to their general wellbeing. The sample faculty members have preferred to adopt the following practices to update their knowledge

- Referring to Journals, E-resources, latest business news and books

- Attending conferences and workshops

- Presenting research papers in the conferences

- Publishing their research papers in the journals of repute

Performance of Institutions on Identified Parameters of Quality and Best Practices: Analysis and Interpretation of the Views and Perceptions Heads of sample

Quality and best practices of the sample Institutions are categorized as activities under teaching and learning, activities under research and publication and activities under extension and community development.

For the effective implementation and monitoring, all the activities performed under teaching and learning further categorized under curricular, co-curricular and extra-curricular activities.

- Curricular activities embrace the teaching and learning 
pedagogy such as ICT enabled GD, seminar presentation, subject presentation, role play, management games, e-based subject presentations and seminars, periodic tests, e-journal based assignments, semester wise viva, compulsory internships, project work etc,. Add on programmes, industry certified programs are also introduced, including the courses on topical subjects such as GST, SAP, Logistics Management, Hospitality Management, Catering Service etc. In order to maintain the quality in the internship and project work and also to watch the progress, a novel system of Internship Report and Work Diary practices has been introduced. Under Co- Curricular activities, the support activities such as special expert lectures, collaborative lectures and training on the use of E journals, SPSS package, demos on Digital Banking, Internship, Project Work and theme-based one day to six day workshops and book review sessions have been introduced.

- Under the Extra Curricular Activities, events such as induction programs, student council activities, cultural activities, sports activities, traditions day celebrations, musical concerts etc, are organised. Celebration of festivals such as Ayudha pooja, Saraswathi pooja, Deepawali, Onam, Christmas, making of short movies on social centric issues, screening of inspirational movies followed by in-depth discussion, open assembly in the beginning of the week as well as at the weekends are implemented and practiced over the period. Further, students are also deputed to various conferences, seminars, competitions, management fests etc, to understand and internalize the developments in their respective fields. Likewise, some of the sample institutions are also organizing on the spot seminars, presentations, debate etc, on the most contemporary issues, allowing the faculty and students to present their views on the subject. In one of the sample Institutions, students are made to write the series of aptitude tests to enhance their skill levels.

$>$ The Trust has given a lot of importance to the research and publication activities at the Institutions. As a result, the 
Institutions functioning under the Trust are regularly bringing out their journals with ISSN Number, which are also indexed. All sample units are regularly bringing out their news magazines, bulletins, annual magazines, conference proceeding etc. Some of the sample institutions are also conducting social surveys along with the identified industry and the findings of the surveys are published. For this academic endeavour, both the students and the faculty join hands together. Furthermore, all the faculty members are encouraged to involve in the publication activities, in the form of preparing and publishing research papers in the journals of national and international repute. Likewise, the members of faculty are also encouraged with financial support and leave facility, to present their research papers and to engage themselves in research activities.

$>$ Trust encourages the students and faculty to take up and participate in the extension and community development activities. Separate annual budgets are created to encourage the extension activities of the sample institutions. Under this category, the extension activities such as the village adoption, blood donation, orphanage visits along with charity in cash and kind, Swatch Bharath Abhiyan, field survey on social centric issues etc, are best practiced over the period. Further, some of the sample institutions are also conducting ecofriendly activities such as conduct of workshops for the public on themes such as terrace gardening, waste management, environment protection etc. Likewise, value based activities are also conducted to provide an insight to the students about values in society. The Trust is also supporting the eco friendly activities of the sample units through provision of renewable energy, rain harvesting, wormycompost etc.

\section{Suggestions}

The study suggests the following Quality Management and Best Practices Model for the Institutions functioning under Laxmi 
Memorial Education Trust as a collective endeavour of the major stakeholders: Management - as the supporters, Heads of the Institutions- as the initiating leaders, faculty- as the true practitioners and the Students- as the keen learners.

\section{Quality Management and Best Practices Model}

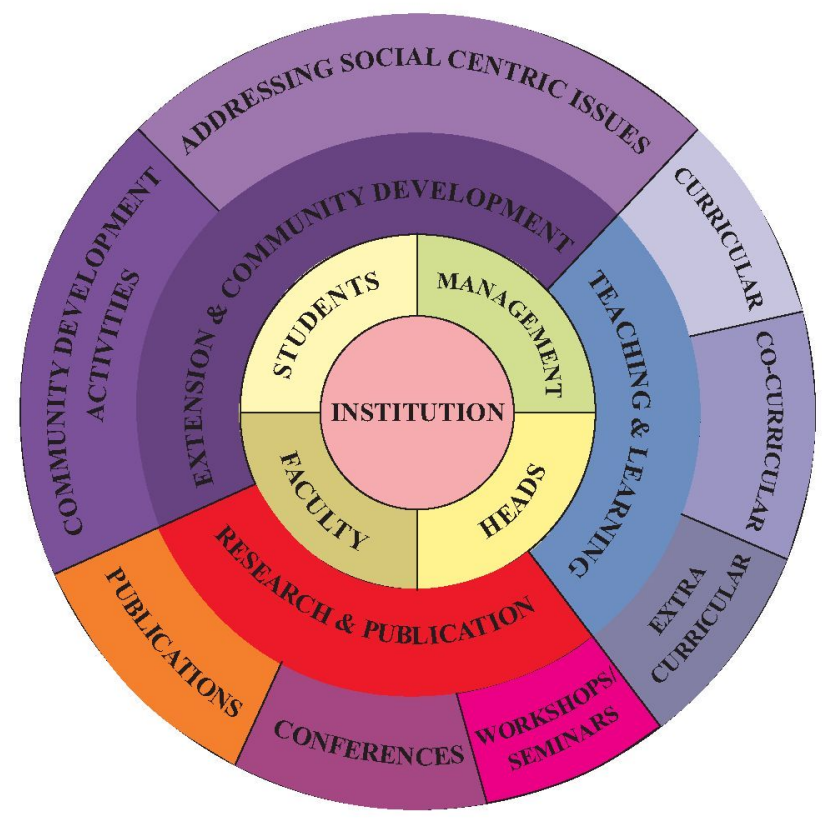

The suggested model is a four circled effort, to ensure the quality in higher education through best practices being developed, adopted, practiced and continued by keeping the best interest of the core stakeholders. The core stakeholders - as given in the second circleare the students, faculty, Institution heads and the Management and it is the collective endeavor of all the stakeholders, which elevates the higher education institutions to the highest standard of quality and excellence. The Institution should remain at the focal point (first circle). As depicted in the third circle, the activities of the institutions may be categorized under three broad sections namely a). Teaching and Learning, b). Research and Publication and c). Extension and Development.

As depicted in the forth circle, under Teaching and Learning various proactive initiatives are suggested to be categorized such as 
curricular, co-curricular and extra-curricular activities. Curricular activities represent the pro-active teaching-learning functions and co-curricular activities represent the support activities to ensure the quality in the teaching and learning. Likewise, the extra-curricular activities represent the support activities to ensure much needed skill component of the curricular requirements and also to ensure hands on experience in applying the theory to practice. Further, to facilitate all curricular, co curricular and extra- curricular activities, various Clubs and Associations should function at the institutions, with the students as office bearers and faculty to guide and supervise.

Curricular Activities to embrace the teaching and learning pedagogy such as ICT enabled GD, seminar presentation, subject presentation, role play, management games, etc. Subject presentations and seminars are mandated to be selected from the EJournals. In addition, other components such as periodic tests, ejournal based assignments, semester wise viva are also suggested to ensure the quality in the delivery of academics. Likewise, the best practices such as compulsory internships, field visits, project work etc, are to be implemented to provide actual learning experiences. Further, to strengthen the quality of the courses offered, add on programmes and certificate programs may be introduced, including the courses on topical subjects such as GST, SAP, Logistics Management, Hospitality Management, Catering Service, patient management etc., to provide a competitive edge. In order to enhance the credibility of these add on programmes, MOUs can be signed with the relevant industry for joint certification. To maintain the quality in the internship and project work and also to watch the progress, proper mechanism such as work diary, internship report etc., are suggested as the best practices. Further, under CoCurricular activities, the support activities such as special expert lectures, collaborative lectures and training on the use of $\mathrm{E}$ journals, SPSS package, etc, may be introduced. Further, demonstrations to be arranged on internship and project work etc, to enhance the learning level of students. Likewise, theme based one day workshops may be organized to make the students more confident and competent. Book review sessions may be introduced to enhance the reading practices 
of students and members of faculty. Monitoring the students during library hours, observing turnover ratio of the library stack, enhancing the library hours if necessary., may be thought of. The prizes may also be announced to the best user of the library.

Under the Extra Curricular Activities, events such as induction programs, student council activities, cultural activities, sports activities, traditional day celebrations, musical concerts etc, may be implemented. Celebration of festivals such as Ayudha pooja, Saraswathi pooja, Deepawali, Onam, Christmas, etc, may also be observed to create and enhance the feeling of belongingness. Further, very distinct and different teaching-learning experiences such as uploading faculty lectures to the individual college website, making of short movies on social centric issues, screening of inspirational movies followed by in-depth discussion, open assembly in the beginning of the week as well as at the weekends may be implemented and practiced. Further, students are to be deputed to various conferences, seminars, competitions, management fests etc, to understand and internalize the developments in their respective fields. Likewise, spot seminars, presentations, debate etc, on the most contemporary issues may be arranged, allowing the faculty and students to present their views on the subject. Students may be allowed to write online aptitude tests to enhance their skill levels.

As presented in the forth circle, under research and publication, it should be the vision of any higher education institution that the educational institution not only to be the center of knowledge dissemination, but also the center of excellence to generate new ideas and knowledge. Hence, the institutions have to assign a lot of importance to the research and publication activities. They have to bring out regularly peer review research journals with ISSN Number, which are also to be indexed. Institutions will have to publish news magazines, bulletins, annual magazines, conference proceeding etc. To understand the pulse of the society, social surveys to be conducted along with the industry and the findings of the surveys to be published. For this academic endeavour, both the students and the faculty should join the hands. Furthermore, all the faculty members 
are to be encouraged to involve in the publication activities, in the form of preparing and publishing research papers in the journals of national and international repute. The members of faculty may be encouraged with financial support and leave facility, to present their research papers and to carryout research activities. Yearly performance evaluation of faculty may be introduced to keep the faculty alert and active.

As shown in the forth circle, under Extension and Community Development activities, students and faculty are to be encouraged take up and participate the extension and community development activities. Separate annual budgets are to be created to encourage the extension activities of the Institutions. The suggested extension activities such as village adoption, blood donation camps, orphanage visits along with charity in cash and kind, Swatch Bharath Abhiyaan, field survey on social centric issues etc, are to be accomplished as best practices. Further, it is also suggested that the institutions to conduct eco-friendly activities such as organising workshops for the public on the theme such as Terrace gardening, waste management, environment protection, banking habits, patient interaction etc. Likewise, value based activities are also to be conducted to provide an insight to the students about values in society. Further, the institutions are to support the eco friendly activities such as provision of renewable energy, rain harvesting, wormy-compost etc.

\section{Conclusion}

The best practice is an inductive approach to quality management in higher education institutions with a focus on practice and continuous improvement. This will help institutions of higher education to play their role effectively in quality sustenance and enhancement. And it should be the vision of every higher education institution in the country. Stakeholders can contribute differently for the realization of this goal by the institutions. Policy makers in the field of education have an important responsibility of creating an enabling policy framework for effective functioning of the institutions. The Management should ensure proper infrastructure and effective governance systems. Teachers have a critical role in building 
competencies of learners through best pedagogic practices. Finally, students, for whom the whole system is designed, should desire and demand the best. Then everything will fall in line.

\section{References}

Ahmad, Wana\&Jiana (2010)Learning health through virtual world: comparative between UK and Malaysia,Procedia - Social and Behavioral $S$ c i e nces, Vo $1 \mathrm{um} \mathrm{e} 9,2010$, P p $11-20$. https://doi.org/10.1016/j.sbspro.2010.12.108

Bittarelli\& Rossi (2010) Best Practices In University E-Learning Centre,Procedia - Social and Behavioral Sciences, Volume 9, 2010, Pp 2125.https://doi.org/10.1016/j.sbspro.2010.12.109.Sallies, Green D. and

Boyne, G.A., Gould-Williams, J.S., Law, J. and Walker, R.M. (2002). Best Value-Total Quality Management for Local Government? Public Money \& Management, 22, 9-16.

Brah, S.A., Wong, J.L. and Rao, B.M. (2000). TQM and business performance in the service sector: a Singapore study. International Journal of Operations \& Production Management, 20, 1293-1312.

Brown R (2013) Mutuality Meets the Market: Analysing Changes in the Control of Quality Assurance in United Kingdom Higher Education 1992-2012, Higher Education Quarterly, John Wiley \& Sons Ltd., Volume 69, Iss. 4, October, 1995 pp 420-437.

Conca, F.J., Llopis, J. and Tarí, J.J. (2004). Development of a measure to assess quality management in certified firms. European Journal of Operational Research, 156, 683-697.

Flynn, B.B., Schroeder, R.G. and Sakakibara, S. (1994). A framework for quality management research and an associated measurement instrument. Journal of Operations Management, 11, 339-366.

Flynn et al., 1994: B. B. Flynn, R. G. Schroeder, and S. Sakakibara, A framework for quality management research and an associated instrument, Journal of Operations Management 11 (4) (1994), pp. 339-366

GitachariSrikanthan\& John Dalrymple (2006) Implementation of A Holistic Model For Quality In Higher Education, Taylor \& Francis, Volume $11, \quad$ I s s u e $1, \quad 2005, \quad$ p p $69-81$ D O I : http://dx.doi.org/10.1080/13538320500077686

Gunduz N and Ozcan D (2010) Learning Styles Of Students From Different Cultures And Studying In Near East University, Procedia - Social and Behavioral Sciences, Volume 9, 2010, Pp 5-10. 
https://doi.org/10.1016/j.sbspro.2010.12.107

Hartley, J. and Downe, J. (2007). The shining lights? Public service awards as an approach to service improvement. Public Administration, 85, 329-353

Harvey L. (1993) - Qualify Assurance in Western Europe; Trends, PracNces and Issues in

Huq, Z. and Stolen, J.D. (1998). Total quality management contrasts in manufacturing and service industries. International Journal of Quality \& Reliability Management, 15, 138-161.

Isabel et, al (2015) Influence of Assessment in the Teaching-learning Process in the Higher Education, Procedia - Social and Behavioral Sciences, Volume 176, 20 February 2015, Pp 458-465. https://doi.org/10.1016/j.sbspro.2015.01.497

Jason M. Lodge \&Agnes Bonsanquet (2013) Evaluating Quality Learning In Higher Education: Re-Examining The Evidence, Quality in Higher Education, Taylor \& Francis Online, Vol. 20, Iss. 1, 2014. DOI: http://dx.doi.org/10.1080/13538322.2013.849787.

Jenicke, L.O., Kumar, A. and Holmes, M.C. (2008), “A framework for applying six sigma improvement methodology in an academic environment", The TQM Journal, Vol. 20 No. 5, pp. 453-62.

Kaynak, H. (2003), "The relationship between total quality management and their effects on firm performance", Journal of Operations Management, Vol. 21,pp. 405-35.

Mangnale\&Rajasekhara M P (2011)Quality Management in Indian Higher Education System: Role of Internal Quality Assurance Cell (IQAC), Asian Journal of Business Management, Maxwell Scientific Organization, 3(4): 251-256, 2011, ISSN: 2041-8752.

Maznah. R, Hussain R and AbuBakar A (2010) Eye on teaching: improving practice through research inquiries, Procedia - Social and Behavioral Sciences, Volume 9, 2010, Pp 403-407. https://doi.org/10.1016/j.sbspro.2010.12.172

Morgan, C. and Murgatroyd, S. (1994). Total quality management in the public service: an international perspective. London: Open University.

Ahire, S.L., Golhar, D.Y. and Waller, M.A. (1996). Development and validation of TQM implementation constructs. Decision Sciences, 27, 2356.

Parrish. D.R (2016)Principles and a Model for Advancing Future-oriented and Student-focused Teaching and Learning,Procedia - Social and 
Behavioral Sciences, Volume 228, 20 July 2016, Pp 311-315. https://doi.org/10.1016/j.sbspro.2016.07.046

Prajogo, D.I. (2005). The comparative analysis of TQM practices and quality performance between manufacturing and service firms. International Journal of Service Industry Management, 16, 217-228.

Santa, T.W., Anderson, C.L. and Berenott, B., (ed). Proceedings of Fifth international Conferencc on Assessing Quality in Higher Education, Indiana University - Purdue University, Indianapolis, USA.Pp.4- 14

Saraph, J.V., Benson, P.G. and Schroeder, R.G. (1989). An instrument for measuring the critical factors of quality management. Decision Sciences, 20(4), 810-829.

Sawanth G.D (2016) Role Of IQAC In Maintaining Quality Standards In Teaching, Learning and Evaluation, Pacific Science Review: Humanities and Social Sciences, Volume 2, Issue 2, July 2016, Pp 66-69 https://doi.org/10.1016/j.psrb.2016.09.016

Sharp $\boldsymbol{S}$ (1995) The Quality of Teaching and Learning in Higher Education: Evaluating the Evidence, Higher Education Quarterly, John Wiley \& Sons Ltd.,Vol. 49, Iss. 4,1995, pp 301-315. DOI: 10.1111/j.14682273.1995.tb01683.x

Stephen Sharp S, Munn P, Paterson L (1997) Quality Assessment in Higher Education: the Scottish Experience, Higher Education Quarterly, John Wiley \& Sons Ltd., Volume 51, Issue 4, October, 1997, pp 286-307.DOI: 10.1111/j.1468-2273.1995.tb01684.x

Sudha T (2013) Total Quality Management In Higher Education Institutions, International Journal of Social Science \& Interdisciplinary Research, IJSSIR, Vol. 2(6), June,2013, pp 121-132.

Watson D (1995) Quality Assessment and 'Self-regulation': the English Experience, 1992-94, Higher Education Quarterly, John Wiley \& Sons Ltd., Volume 49, Iss. 4, October, 1995 pp 326-340.DOI: 10.1111/j.14682273.1995.tb01685.

Waugh, R.F. (2002). Academic staff perceptions of administrative quality at universities. Journal of Educational Administration, 40, 172-188.

Woollard A (1995) Core Skills and the Idea of the Graduate, Higher Education Quarterly, John Wiley \& Sons Ltd, Volume 49, Iss.- 4October 1995,pp 316-325 